\title{
Factors Related to Pneumonia in Children Under Five Years in Banjarmasin
}

\author{
Widya Nursantari*, Erida Wydiamala**, Lenie Marlinae ***, Roselina Panghiyangani ****, Meitria Syahadatina \\ Noor $* * * * * *$
}

* Master of Public Health, Faculty of Medicine, Lambung Mangkurat University, Indonesia
**Faculty of Medicine, Lambung Mangkurat University, Indonesia
*** Public Health Study Program, Faculty of Medicine, Lambung Mangkurat University, Indonesia
**** Department of Biomedicine, Faculty of Medicine, Lambung Mangkurat University, Indonesia
**** Department of Public Health, Faculty of Medicine, Lambung Mangkurat University, Indonesia

DOI: 10.29322/IJSRP.10.06.2020.p10275

http://dx.doi.org/10.29322/IJSRP.10.06.2020.p10275

\begin{abstract}
Pneumonia is the number one cause of death in children under five in Indonesia. South Kalimantan Province occupies fourth with the case of $66,72 \%$ and Banjarmasin City has recorded the highest incidence of pneumonia in children under five as many as 2.587 cases. The incident of pneumonia influenced by various factors, including environmental sanitation conditions and behaviour. This study aims to determine the relationship between risk factors of the physical environment of house and behaviour with the incidence of pneumonia in children under five in Banjarmasin CityThis study was an analytic observational with a case-control study. The sample was selected by purposive sampling with a sample size of 170 mothers with children under five covering 85 cases and 85 controls. Data analysis was performed using frequency distribution, chi-square test and binary regression logistic. The result of chi-square test showed that there was a relationship of ventilation $(\mathrm{p}=0.000)$, lighting $(\mathrm{p}=0.000)$, temperature $(\mathrm{p}=0.000)$, humidity $(\mathrm{p}=0.002)$, smoking behaviour $(\mathrm{p}=0,001)$ and handwash behaviour $(\mathrm{p}=0,000)$ with pneumonia incidence. Furthermore, binary logistic regression test results show that ventilation $\mathrm{OR}=8,59$ is the most influence with the incidence of pneumonia in children under five. Ventilation is the most dominant risk factors in the incidence of pneumonia in children under five in Banjarmasin City.
\end{abstract}

Index Terms- pneumonia, children under five, environment factor, smoking behaviour, handwash behaviour

\section{INTRODUCTION}

A cute Respiratory Infection (ARI) is the leading cause of infectious disease morbidity and mortality in the world, with mortality reaching 4.25 million every year (1). World Health Organization (WHO) shows that the number of deaths caused by ARI in Balinese children in the world in 2013 was 45.6 per 1,000 live births. Indonesia has become one of the developing countries with a very high mortality rate of ARI cases in infants, children, and the elderly (2). One of them, pneumonia, is an acute respiratory infection caused by a virus, bacteria or fungus that hurts the lungs. Infection can spread from someone who is exposed to the environment or direct contact with infected people, usually through the hands or inhaling droplets in the air due to coughing or sneezing (3). Based on the 2018 Riskesdas data, the prevalence of pneumonia for all age groups increased from $1.6 \%$ (2013) to 2\% (2018). World Health Organization, shows the mortality rate of children under-five due to pneumonia in the world is 43 deaths per 1000 live births and is the number one deadly disease among children under five among infectious diseases with 922,000 deaths (16\%), especially in South Asia and sub-Africa -Sahara (4). UNICEF reports that 6 out of 10 children under five die from pneumonia in 10 countries: Chad (24\%), Nigeria (19\%), Angola (18\%), Ethiopia (16\%), India (15\%), Pakistan (15\%), Afghanistan (16\%), Indonesia (15\%), Congo $(14 \%)$, and China (12\%). Africa and Southeast Asia, including countries with the highest incidence of pneumonia cases by $30 \%$ and $39 \%$ which resulted in the global burden of (5) and disability amounted to $15 \%$ in children under five are caused by pneumonia (6). Based on reports of 34 provinces of pneumonia cases that occur in children under-five, there are five provinces with the highest coverage of pneumonia cases, namely DKI Jakarta (98.66\%), North Kalimantan (74.76\%), Bangka Belitung Islands (67.21\%), South Kalimantan (66.72\%), and Central Sulawesi (66.59\%) (6).

Based on the report of the South Kalimantan Provincial Health Office in 2017 the city of Banjarmasin ranks first with the incidence of pneumonia in children under-fives a total of 3,507 cases and in 2018 a total of 2,587 cases. From 26 public health centre in Banjarmasin City, it was found that in 2018 the total number of pneumonia sufferers was 26,179 cases and 10,067 cases in children under five (7). According to Maryunani (2013) factors that can cause pneumonia in children under five are environmental factors, intrinsic/host factors (such as nutritional status, children under-five immunization status, birth weight, sex, age of children under-five, giving vitamin A, exclusive breastfeeding) and extrinsic factors (education, parity, economic status, knowledge, health behaviour) (8). Besides, behavioural factors also affect the incidence of pneumonia in children underfive. The behaviour of parents who pay less attention to personal 
hygiene and children under-five is one of the factors that can cause pneumonia (9). Based on the results of Riskesdas 2013, it was found that the behaviour of clean and healthy people in Indonesia was 32.3\%, for the Province of South Kalimantan was below the national percentage of $25.5 \%$ (10). Based on the data above shows that the incidence of pneumonia is still high in the city of Banjarmasin, Indonesia and even in the world, so pneumonia is a major public health problem that contributes to the high mortality rate of children under five in Indonesia.

\section{RESEARCH METHOD}

This research uses quantitative research methods using analytic observational research designs through a case-control approach. This research was conducted in the public health centre in Banjarmasin, namely public health centre of Alalak Selatan, Cempaka Putih, 9 November, Sungai Jingah which was held on the month in August 2019 - January 2020. The population of this study were mothers who had children of children aged 12 to 59 months in public health centre Banjarmasin 2018, amounting to 10,365 people. The sample of this study was divided into two cases: the case group was mothers who had children under-fives with pneumonia who had been diagnosed based on history taking and physical examinations by the local public health centre while the control group were mothers who had healthy children underfives and visited the public health centre at almost the same time as case finding and meet the inclusion and exclusion criteria. The number of samples needed to become respondents in this study was 170 people, namely 85 case groups and 85 control groups.

The research instruments used in this study were questionnaire, meter and lux meter. The questionnaire was tested for validity and reliability in the Banjarmasin Indah Public Health Center area with 30 respondents. Analysis of the data in this study using analysis descriptive to see the frequency distribution for each variable, the analysis of the statistics by using Chi-square and multiple logistic regression test.

\section{FINDINGS}

Table 1. Univariate Analysis of Research Variables

\begin{tabular}{|c|c|c|c|c|}
\hline \multirow{2}{*}{ Variable } & \multicolumn{2}{|c|}{ Case } & \multicolumn{2}{|c|}{ Control } \\
\hline & $\mathbf{n}$ & $\%$ & $\mathbf{n}$ & $\%$ \\
\hline \multicolumn{5}{|l|}{ 1. Ventilation area } \\
\hline Eligible (if $\geq 10 \%$ of floor & 17 & 20 & 59 & 69.42 \\
\hline area) & 68 & 80 & 26 & 30.58 \\
\hline $\begin{array}{l}\text { Not-eligible (if < } 10 \% \text { floor } \\
\text { area) }\end{array}$ & & & & \\
\hline \multicolumn{5}{|l|}{ 2. Lighting } \\
\hline Eligible (lighting $\geq 60$ lux) & 404 & 47.06 & 59 & 69.42 \\
\hline $\begin{array}{l}\text { Not-eligible (lighting <60 } \\
\text { lux) }\end{array}$ & 5 & 52.94 & 26 & 30.58 \\
\hline \multicolumn{5}{|l|}{ 3. Temperature } \\
\hline Eligible $(18$ o C-30 o C) & 11 & 12.94 & 45 & 52.94 \\
\hline $\begin{array}{l}\text { Not-eligible }(<18 \text { o } C \text { and } \\
>30 \circ C)\end{array}$ & 74 & 87.06 & 40 & 47.06 \\
\hline \multicolumn{5}{|l|}{ 4. Humidity } \\
\hline Eligible (40\% -70\%) & 36 & 42.36 & 42 & 49.41 \\
\hline $\begin{array}{l}\text { Not-eligible }(<40 \% \text { and } \\
>70 \%)\end{array}$ & 49 & 57.64 & 43 & 50.59 \\
\hline
\end{tabular}

5. Types of house construction

Permanent

Not permanent

6. Types of house floors

Permanent

Not permanent

7. Occupancy density

Not solid

Solid

8. Smoking behaviours in the house

No ordinary smoking

Regular smoking

9. Handwashing behaviours

Washing hands

Unusual hand washing

$\begin{array}{cccc}0 & 0 & 0 & 0 \\ 8 & 100 & 85 & 100\end{array}$

$\begin{array}{cccc}0 & 0 & 0 & 0 \\ 85 & 100 & 85 & 100\end{array}$

$\begin{array}{llll}38 & 44.71 & 59 & 69.41\end{array}$

$\begin{array}{llll}47 & 55.29 & 26 & 30.59\end{array}$

$\begin{array}{cccc}5 & 5.88 & 23 & 27.06 \\ 80 & 94.12 & 62 & 72.94\end{array}$

$34 \quad 40 \quad 671 \quad 78.82$

$\begin{array}{llll}51 & 60 & 8 & 21.18\end{array}$

Table 2. Bivariate Analysis with Chi-Square Test

\begin{tabular}{|c|c|c|c|c|c|c|}
\hline \multirow{2}{*}{ Variable } & \multicolumn{2}{|c|}{ Case } & \multicolumn{2}{|c|}{ Control } & \multirow{2}{*}{$\begin{array}{c}p- \\
\text { value }\end{array}$} & \multirow{2}{*}{ OR } \\
\hline & $\mathbf{n}$ & $\%$ & $\mathbf{n}$ & $\%$ & & \\
\hline \multicolumn{7}{|l|}{ 1. Ventilation area } \\
\hline $\begin{array}{l}\text { Eligible (if } \geq 10 \% \text { of } \\
\text { floor area) }\end{array}$ & 17 & 20 & 59 & 69.4 & \multirow{2}{*}{0.000} & \multirow{2}{*}{9.077} \\
\hline $\begin{array}{l}\text { Not-eligible } \\
\text { (if <10\% floor area) }\end{array}$ & 68 & 80 & 26 & 30.58 & & \\
\hline \multicolumn{7}{|l|}{ 2. Lighting } \\
\hline $\begin{array}{l}\text { Eligible (lighting } \geq \\
60 \text { lux) }\end{array}$ & 40 & 47.06 & 59 & 69.4 & \multirow[t]{2}{*}{0.003} & \multirow[t]{2}{*}{2.553} \\
\hline $\begin{array}{l}\text { Not-eligible } \\
\text { (lighting <60 lux) }\end{array}$ & 45 & 52.94 & 26 & 30.58 & & \\
\hline \multicolumn{7}{|l|}{ 3. Temperature } \\
\hline Eligible $(18 \mathrm{o} C-30 \circ \mathrm{C})$ & 11 & 12.94 & 45 & 52.9 & \multirow{2}{*}{0.000} & \multirow{2}{*}{7.568} \\
\hline $\begin{array}{l}\text { Not-eligible } \\
(<18 \text { oC and >30 o C })\end{array}$ & 74 & 87.06 & 40 & 47.06 & & \\
\hline \multicolumn{7}{|l|}{ 4. Humidity } \\
\hline Eligible $(40 \%-70 \%)$ & 36 & 42.36 & 42 & 49.4 & \multirow{2}{*}{.356} & \multirow{2}{*}{1.329} \\
\hline $\begin{array}{l}\text { Not-eligible }(<40 \% \\
\text { and }>70 \%)\end{array}$ & 49 & 57.64 & 43 & 50.59 & & \\
\hline \multicolumn{7}{|l|}{$\begin{array}{l}\text { 5. Types of house } \\
\text { construction }\end{array}$} \\
\hline Permanent & 0 & 0 & 0 & 0 & \multirow{2}{*}{-} & \\
\hline Not permanent & 85 & 100 & 85 & 100 & & \\
\hline \multicolumn{7}{|l|}{ 6. Types of house floors } \\
\hline Permanent & 0 & 0 & 0 & 0 & \multirow[t]{2}{*}{ - } & \multirow[t]{2}{*}{-} \\
\hline Not permanent & 85 & 100 & 85 & 100 & & \\
\hline \multicolumn{7}{|l|}{ 7. Occupancy density } \\
\hline Not solid & 38 & 44.71 & 59 & 69.41 & \multirow[t]{2}{*}{0.000} & \multirow{2}{*}{2.807} \\
\hline Solid & 47 & 55.29 & 26 & 30.59 & & \\
\hline \multicolumn{7}{|l|}{ 8. Smoking } \\
\hline $\begin{array}{l}\text { behaviours in the } \\
\text { house }\end{array}$ & 5 & 5.88 & 23 & 27.06 & \multirow{2}{*}{0.001} & \multirow{2}{*}{5.935} \\
\hline $\begin{array}{l}\text { No ordinary smoking } \\
\text { Regular smoking }\end{array}$ & 80 & 94.12 & 62 & 72.94 & & \\
\hline \multicolumn{7}{|l|}{$\begin{array}{l}\text { 9. Handwashing } \\
\text { behaviours }\end{array}$} \\
\hline Washing hands & 34 & 40 & 67 & 78.82 & \multirow[t]{2}{*}{0.000} & 5.583 \\
\hline $\begin{array}{l}\text { Unusual hand } \\
\text { washing }\end{array}$ & 51 & 60 & 18 & 21.18 & & \\
\hline
\end{tabular}


Table 3. Multivariate Analysis with Logistic Regression Test

\begin{tabular}{llccccc}
\hline No & Variable & B & Wald & Sig & $\begin{array}{c}\text { Exp } \\
\text { (B) }\end{array}$ & $\begin{array}{c}\text { 95\% CI } \\
\text { Lower } \\
\text { Upper }\end{array}$ \\
\hline 1 & $\begin{array}{l}\text { Ventilation } \\
\text { area }\end{array}$ & 2.11 & 22.88 & 0.000 & 8.28 & $3.48-19.69$ \\
2 & Lighting & 0.92 & 4.47 & 0.034 & 2.52 & $1.07-5.96$ \\
3 & $\begin{array}{l}\text { Temperature } \\
4\end{array}$ & 1.49 & 9.41 & 0.002 & 4.45 & $1.71-11.55$ \\
& $\begin{array}{l}\text { Occupancy } \\
\text { density }\end{array}$ & 0.77 & 2.93 & 0.087 & 2.17 & $0.89-5.26$ \\
5 & $\begin{array}{l}\text { Smoking } \\
\text { behaviour }\end{array}$ & 1.25 & 3.29 & 0.070 & 3.49 & $0.61-5.66$ \\
6 & $\begin{array}{l}\text { Handwashing } \\
\text { behaviour }\end{array}$ & 1.43 & 11.19 & 0.001 & 4.20 & $0.904-13.47$ \\
\hline
\end{tabular}

\section{DISCUSSION}

The most dominant relationship to the incidence of pneumonia in children under five is ventilation. This result in line with the results Khasanah et al. (2016) which states that there is a significant relationship between the area of ventilation of the house with the incidence of pneumonia in children under-five, namely children under-five living in homes with ventilation areas that do not meet the requirements have a risk of 3.6 times greater (11). Also in line with the results of research by Wulandari et al. (2016) who found a significant relationship between ventilation area and potential transmission of pneumonia with $\mathrm{OR}=3.85$, children under five living in homes with ventilation area did not meet the risk of 3.85 higher risk of pneumonia (12). Ventilation has a very important function to ensure the quality and adequacy of air circulation in the room, with ventilation will be able to free the room air from pathogenic bacteria because there is always a continuous flow of air. Indoor airflow is not only one-way flow, but air flow must be able to provide fresh inlet air and remove dirty air where the air in and out mechanism must be balanced (13). Bacteria that are often in the air are bacteria that live in the human respiratory tract, which often participate when sneezing/coughing, breathing or talking (14 ). Poor ventilation can cause inadequate air exchange and facilitate the growth of microorganisms, such as Streptococcus aureus, Legionella, Clostridium are easily found in a room (15).

Comfortable air temperature ranges from 18 o- 30 o C. This means that children under five who live in homes with temperatures that do not meet the requirements have a risk of 4.45 times higher for pneumonia compared with children under five who live in homes with temperatures that meet the condition. This result in line with the results Darmawati et al. (2015) shows that children under five years old who live in homes with temperature and humidity do not qualify for risk of being 5.9 times more likely than children under five years old who live at home with temperature conditions (16). Extreme temperature changes can affect children under-fives body condition. The immune system of children under-five can decrease due to the temperature being too hot or cold because children under-fives are still very vulnerable to adjusting the surrounding temperature (13). At a state of high enough house temperature, that is $>300 \mathrm{C}$ microorganisms that cause pneumonia will be able to grow to its optimum so that it will survive in the air in the house. Temperature inside the house can be influenced by season, outside air temperature, sunlight, and the flow of fresh air that enters through the ventilation holes that can maintain the temperature of the air inside the house, so that if the ventilation is less, the temperature inside the house will tend to increase. (13). In addition, it is also influenced by the material and colour of the roof and walls of the house, ventilation and angle of the roof space, as well as the ceiling material (ceiling of the house). Based on the results of this study, it is known that the ventilation area of children under five with pneumonia is generally very lacking.

Healthy homes require adequate lighting, especially sunlight in which there is ultraviolet light with wavelengths $<290 \mathrm{~nm}$. Ultraviolet light at a wavelength of $253.7 \mathrm{~nm}$ can kill germs, bacteria, viruses, and fungi that can cause respiratory infections by damaging the microbial DNA (17). The results of the study of Khasanah et al. (2016) stated that children under five years old who live in homes with natural lighting intensity did not meet the requirements obtained $\mathrm{OR}=5.7$, meaning that the risk was 5.7 times greater than suffering from pneumonia compared to children under five with natural lighting intensities meeting the requirements (11). This is also in line with Pusparini's research (2017) which shows a significant relationship between lighting with the incidence of pneumonia with an $\mathrm{OR}=7.5$, meaning that children under five who live with lighting do not qualify to have a risk factor of 7.5 times greater than the incidence of pneumonia (18).

The behaviour of washing hands with soap and clean running water is part of healthy living behaviour which is one way to increase public awareness about maintaining personal health and the importance of behaving clean and healthy. Proper and proper handwashing aims to reduce the number of microorganisms present in the hands and prevent the spread to areas that are not contaminated (19). This means that children under five years old who live at home with mothers who do not have the behaviour of washing their hands be 4.20 times more likely to get pneumonia. The results of this study are in line with research by Rani et al. (2016) showed that there is a relationship between a clean and healthy lifestyle through washing hands with the incidence of pneumonia, a child under-five (20). Pratiwi's research (2018) states that there is a significant correlation between handwashing behaviours after coughing/sneezing on the incidence of pneumonia in children under five with $\mathrm{p}$-value $=0.039$ and OR value $=1.846$, indicating that children under-fives who have family members who do not have the behaviour of washing their hands after coughing/sneezing 1,846 times greater risk of pneumonia in infants (21).

After knowing the variables associated with the incidence of pneumonia in the city of Banjarmasin, it is expected that the relevant agencies will intensify efforts to educate pneumonia risk factors in children under five, especially education on behaviours or patterns of parental behaviour, socialization of rules and guidelines for building healthy homes and striving for home construction or repair according to the standard. 


\section{CONCLUSION}

Based on the results of research and discussion, it can be concluded as follows:

1. There is a relationship between ventilation and the incidence of pneumonia in children under five in Banjarmasin City ( $\mathrm{p}$ $=0.000, \mathrm{OR}=9.07,95 \% \mathrm{CI}=4.490-18.348$ ).

2. There is a correlation between lighting and the incidence of pneumonia in children under five in Banjarmasin City ( $\mathrm{p}=$ $0.003, \mathrm{OR}=2.53,95 \% \mathrm{CI}=1.363-4.783$ ).

3. There is a correlation between temperature and the incidence of pneumonia in children under five in Banjarmasin City ( $\mathrm{p}$ $=0.000, \mathrm{OR}=7.65,95 \% \mathrm{CI}=3.528-16.235$ ).

4. There is no relationship between house humidity with the incidence of pneumonia in children under five in Banjarmasin City $(\mathrm{p}=0.356, \mathrm{OR}=1.329,95 \% \mathrm{CI}=0.726$ 2.434) .

5. It cannot be statistically tested between house walls and the incidence of pneumonia in children under five in Banjarmasin City because there are no variations in the case or control groups.

6. It cannot be statistically tested between the type of house floor with the incidence of pneumonia in children under five in Banjarmasin because there are no variations in the case or control groups.

7. There is a relationship of residential density with the incidence of pneumonia in children under five in Banjarmasin City $(\mathrm{p}=0.000, \mathrm{OR}=2.17,95 \% \mathrm{CI}=1.496$ 5.265) .

8. There is a relationship between smoking behaviours in the home with the incidence of pneumonia in children under five in Banjarmasin City $(\mathrm{p}=0.001, \mathrm{OR}=5.93,95 \% \mathrm{CI}=2.135$ 16.500)

9. There is a relationship between handwashing behaviours with the incidence of pneumonia in children under five in Banjarmasin City $(\mathrm{p}=0.000, \mathrm{OR}=5.58,95 \% \mathrm{CI}=2.836$ 10.994).

10. The most dominant risk factor for the incidence of pneumonia in children under five in Banjarmasin City is the area of ventilation of houses that do not meet the requirements (adjusted OR 8.28).

\section{REFERENCES}

1. Najmah. (2016) Epidemiologi Penyakit Menular. CV. Trans Info Media. East Jakarta.

2. WHO. (2013) Pneumonia. Fact sheet $N^{\circ} 331$ [cited 2013 Nov 13]. Available from: http://www.who.int/mediacentre/factsheets/fs331 / en / 2013.

3. Jones, B., Dean, N., Wunderink, R., Sockrider, M. (2016) What is Pneumonia. Am J Respir Crit Care Med. 193; 1-2.

4. WHO. (2015) Pneumonia. Fact Sheet No 331. Geneva, Switzerland. Available from: www.who.int/mediacentre/factsheets/fs331/en/.

5. WHO, UNICEF. (2018) World Pneumonia Day 2018. Available from https://www.who.int/maternal_child_adolescent/child/world-pneumoniaday 2018 / en /.
6. Ministry of Health Republic of Indonesia (2018) Indonesian Health Profile Data and Information 2017. Publisher of the Indonesian Ministry of Health. Jakarta.

7. Banjarmasin City Health Office. (2017) Banjarmasin City Health Office Report 2017.

8. Maryunani. (2013) Clean and Healthy Behavior (PHBS). CV Trans Info Media (TIM). Jakarta.

9. Abiyoga, A., Ana, RA., Arifin, RF. (2018) Relationship between Parental Health Behavior and Child Nutritional Status Against Common Cold Events in Children under-fives. Darul Azhar Journal. 5 (1); 1-7.

10. Riskesdas. (2013) Basic Health Research. Ministry of Health of the Republic of Indonesia. Jakarta.

11. Khasanah, M., Suhartono, Dharminto. (2016) Relationship between Environmental Conditions in the Home and the Occurrence of Pneumonia in Children under-fives in the Work Area of Puring Public health center, Kebumen Regency. Journal of Public Health. 4 (5); 27-34.

12. Wulandari, PS., Suhartono, Dharminto. (2016) Relationship between the Physical Environment of the House and the Occurrence of Pneumonia in Children under-fives in the Work Area of the Jatisampurna Health Center in Bekasi City. Journal of Public Health. 4 (5); 125-133.

13. Retna, U., Umi NF. (2015) Characteristics of Pneumonia Occurrence in Children under-fives in Health Center Wanadadi 1 Banjarnegara District in 2014. Medsains. 18-22.

14. Hidayat, CW., Suhartono, Dharminto. (2016) Relationship between Physical Conditions in the House and Pneumonia in Children under-fives in the Jatibarang Community Health Center, Indramayu Regency. Journal of Public Health. 4 (3); 749-57.

15. Fikri, BA. (2016) Risk Factor Analysis of Breastfeeding and Room Ventilation for the Occurrence of Children under-five Pneumonia. The Indonesian Journal of Public Health. 11 (1); 14-27.

16. Darmawati, AT., Sunarsih, E., Trisnaini, I. (2016) Relationship between Physical Conditions and Home Behavior with the Incidence of Pneumonia in Children under-fives in the Work Area of the Yosomulyo Community Health Center Metro City. Journal of Public Health. 7 (1); 6-13.

17. Sari, EL., Suhartono, Joko, T. (2014) Relationship between the Physical Conditions of the Home Environment and the Occurrence of Pneumonia in Children under-fives in Pati I Public health center Pati Pati. Journal of Public Health. 2 (1); 56-61.

18. Pusparini, H., Cahyono, T., Budiono. (2017) Risk of Physical Condition of Houses with Incidence of Pneumonia in Children under-fives in the Region of Sumpiuh II Health Center, Banyumas Regency 2016. Journal of Environmental Health. 36 (1); 75-82.

19. Muchtar, M., Lola FA. (2016) A Picture of Hand Washing with Soap (CTPS) Behavior for Students in SDN 41 Seberang Padang, Padang Selatan District in 2015. Journal of Nursing, Midwifery \& Public Health. 3 (2).

20. Rani, SV., Garina, LA., Ekowati, R. (2016) Relationship between Immunization Status, Clean and Healthy Lifestyle through Handwashing with Pneumonia in Children under-fives. Proceedings of Medical Education. 2 (2); 594-601.

21. Pratiwi, DS., Yunus, M., Gayatri, RW. (2018) Relationship Between Parental Behavior Factors and the Occurrence of Children under-five Pneumonia in the Work Area of the Dinoyo Community Health Center in Malang City. Journal of Preventia. 3 (2); 1-13.

\section{AUTHORS}

First Author - Widya Nursantari, Master of Public Health, Faculty of Medicine, Lambung Mangkurat University, Indonesia. Second Author - Erida Wydiamala, Faculty of Medicine, Lambung Mangkurat University, Indonesia.

Third Author - Lenie Marlinae, Public Health Study Program, Faculty of Medicine, Lambung Mangkurat University, Indonesia. Fourth Author - Roselina Panghiyangani, Department of Biomedicine, Faculty of Medicine, Lambung Mangkurat University, Indonesia.

Fifth Author - Meitria Syahadatina Noor, Department of Public Health, Faculty of Medicine, Lambung Mangkurat University, Indonesia. 
Correspondence Author - Widya Nursantari, Master of Public Health, Faculty of Medicine, Lambung Mangkurat University, Indonesia, email: widyanursantari @ yahoo.com 